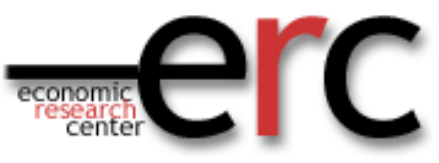

ERC Working Papers in Economics 08/02 April 2008

\title{
Private Supplementary Tutoring in Turkey Recent Evidence on its Recent Aspects
}

\author{
Aysit Tansel \\ Department of Economics \\ Middle East Technical University \\ Ankara 06531 Turkey \\ Email: atansel@metu.edu.tr \\ Fatma Bircan \\ Department of Economics \\ Karaelmas University \\ 67100 Zonguldak, Turkey \\ Email: bircanf@gmail.com
}




\title{
Private Supplementary Tutoring in Turkey Recent Evidence on Its Various Aspects*
}

\author{
by \\ Aysit Tansel $^{* *}$ \\ Department of Economics \\ Middle East Technical University \\ 06531 Ankara, Turkey \\ and \\ Institute for the Study of Labor (IZA) Bonn, Germany \\ e-mail: atansel@metu.edu.tr \\ and \\ Fatma Bircan \\ Department of Economics \\ Karaelmas University \\ 67100 Zonguldak, Turkey \\ e-mail: bircanf@gmail.com
}

July, 2007

Key Words: Private Tutoring, Education, Demand for Education.

JEL Codes: I20, I21, I22

\begin{abstract}
:
This paper first describes the educational system in Turkey an the two national examinations for advancing upper levels of schooling which give raise to the demand for private tutoring called "dersane" in Turkish. Second, the evolution of the Private tutoring Centers (PTC) are described and compared with the high schools in the country. Third, geographical distribution of the PTC, general high schools and the proportion of high school age population are compared over the provinces to give an idea about special equity issues. Other topics addressed include gender and PTC students, disruption of mainstream education, determinants of the demand for services of the PTCs, cost of PTCs and evidence on the effectiveness of PTCs.

\footnotetext{
* This paper is prepared at the kind request of Professor Dr. Mark Bray, Director UNESCO International Institute for Educational Planning (IIEP). We are grateful to him for his encouragement. We also thank Emmanuel Souzo also of the IIEP, for providing helpful comments on the manuscript. Any errors are our own.

***Corresponding Author.
} 
Private Supplementary Tutoring in Turkey: Recent Evidence on Its Various Aspects

\section{Table of Contents}

1. Introduction

2. Education System in Turkey

Two National Examinations

\subsection{A Transition to Secondary Education}

\subsection{B Transition to Universities}

Why is there a high demand for University Education in Turkey?

3. Recent Developments in the Private Tutoring Centers in Turkey

Forms of Private Tutoring

Recent Trends in Private Tutoring Centers

Private Tutoring Center Students and Gender

Private Tutoring Centers and Disruption of Mainstream Classes

Determinants of Receiving Private Tutoring

4. Geographic Distribution of Private Tutoring Centers and High Schools

5. Effectiveness of Private Tutoring Centers

The Cost of the Private Tutoring Centers

6. Conclusion

7. References 


\section{List of Acronyms and Abbreviations}

PTC : Private Tutoring Center (Dersane).

YÖK: Higher Education Board of Turkey (Yüksek Öğretim Kurumu)

OKS: Examination for Selection and Placement of Students for Secondary Education Schools. (Örta Öğretim Kurumları Öğrenci Seçme ve Yerleştirme Sınavı).

ÖSS: Student Selection Examination (Öğrenci Seçme Sınavı).

ÖSYM: Student Selection and Placement Center (Öğrenci Seçme ve Yerleştirme Merkezi).

ÖZDEBİR: Association of Private tutoring Centers (Özel Dersaneler Birliği).

GÜVENDER: Association of The Owners of Güven Private Tutoring Centers (Güven Dersane Sahipleri Derneği).

TÖDER: Association of the all Private Educational Establishments (Tüm Özel Öğretim Kurumları Derneği).

TED: Turkish Educational Association (Türk Eğitim Derneği).

KPDS: Language Profiiency Examination for Public Servants (Kamu Personeli Dil Sinav1).

KPSS: Examination for Selection of Public Servants (Kamu Personeli Seçme Sınavı). 


\section{Introduction}

Private supplementary tutoring has been wide-spread in the East Asian countries for sometime. During the recent decades it has grown substantially in all other regions of the world including Western developed countries and more recently in the East European countries.

Recently, there is an upsurge of studies on the supplementary private tutoring. Stevenson and Baker (1992) were one of the first to investigate this topic in Japan. They were followed more recently by Bray (1999) who draws attention of the international community on supplemental private tutoring with works such as Bray (2003), Bray and Kwok (2003), Silova and Bray (2006). Bray (1999) also coined the word "shadow education" for the supplementary private tutoring since it develops parallel to the mainstream education but with different characteristics. Bray (2006) provides a review of the recent studies in this area.

Private tutoring is a large-scale industry especially in the countries where there are national examinations in selecting students who will advance through upper educational levels. The system of private tutoring has developed in Turkey as a result of such national examinations. In 2006 there were almost four thousand registered private tutoring centers with over one million students and about fifty thousand teachers. Tansel and Bircan $(2005 ; 2006)$ are the two important studies devoted to private tutoring in Turkey. Gök (2006), Akgün (2005) and Güvercin (2005) are the other studies that indicate the recent attention in Turkey to this topic. Recently, several governmental and non-governmental organizations prepared extensive reports on the university entrance examination system and the private tutoring centers in Turkey. These reports included 
Turkish Educational Association (TED) (2005), Higher Education Board (YÖK) (2007) and Trade Union of Educators (Egitim-Sen) (2007). All of these reports will be reviewed and referred to in this study.

These reports address the interrelated problems of university entrance examination system and the accompanying system of private tutoring which is considered as a key factor in securing a place at a university program and the orientation of the secondary education students for general versus "special".high schools.

This study will examine various aspects of supplemental private tutoring in Turkey by drawing largely on the recent evidence. The organization of the paper is as follows. Section 2 will review the educational system in Turkey and the two national examination systems that are mainly responsible for the development of private tutoring system. Section 2.1.A addresses the transition from basic education to high schools which creates demand for the services of PTCs. This section also reviews the March 2007 government intervention in the examination system at this level. Section 2.1.B addresses the transition from high schools to universities which creates a second wave of demand for services of the PTC. Section 2.2 addresses the reasons for the high demand for university Education in Turkey and therefore the demand for services of the PTCs. Section 3 reviews, the forms of private tutoring in Turkey. Recent developments in the in the Private tutoring centers and the secondary schools are examined and compared in this section also. Gender of the attendants of the PTCs, determinants of the demand for services of PTCs and disruption of mainstream classes are all addressed in this section. Provincial distribution of private tutoring centers, general high schools and the high school age population are considered in Section 4. This section is expected to shed light 
on the spatial equity issues in the distribution of PTCs and high schools. Section 5 will review evidence on effectiveness of PTCs and their cost. Finally, Section 6 will provide concluding remarks.

\section{Education System in Turkey}

Education system in Turkey consists of basic education, secondary education and tertiary education. Until 1997 primary schooling of five years was the only compulsory level. In 1997 it was combined with three years of middle schooling and the total of 8 years became compulsory and called basic education. This is followed by 3-4 years of secondary education consisting of general and vocational high schools. In 2005-2006 secondary education schools were extended to 4 years of training. Universities take 2-6 years depending on the program of study. Although state is the major provider, there are a number of private providers at all of the three levels of education. In view of the excess demand for the tertiary level education, government has been increasing the number of universities. In 1992, 25 public universities were established. In 2006, 15 new universities are established. Currently there are 93 universities 25 of which are private (YÖK, 2007). A recent law of April 2007 stipulated the establishment of 17 additional new universities.

\subsection{Two National Examinations in Turkey}

\subsection{A Transition to Secondary Education}

There are two national examinations in Turkey which determine who will advance to the upper levels of schooling? The first examination is called OKS (Secondary School Examination) in short. It is administered by the Ministry of 
Education. It is taken by the graduates of basic education who would like to be placed at one of the special and prestigious high schools. Such high schools which are believed to provide better quality education and their graduates are believed to have higher chance of success at the university entrance examination. Some of these schools provide a year of English courses before the start of the regular classes which may be held in English. These schools include Anatolian high schools (general and vocational), Science high schools, Super high schools and private high schools. There are about 700 such high schools. The students who can not be placed at these high schools have the option of attending general high schools or vocational high schools. There is no restriction on attendance on the latter schools. Therefore OKS is relevant only for students who would like to attend "special" high schools. Students who would like to attend other high schools are not required to take this examination.

For this reason parents spend on private tutoring of their children for preparation to the OKS examination, in order to place them into special high schools. Special high schools are believed to increase their children's chances of placement at a university program.

Indeed, responses to the Question 13 in Table 6 show that 67 percent of the senior high school graduates, 67 percent of the university graduates and 74 percent of the teachers and administrators agree that quality of high school is an important determinant of success at university entrance examination. Response to the Question 14 in the same table show that 50 percent of the parents indicated that while choosing a high school for their child they considered past performance of the high school at the university entrance examination. 
In an attempt to reduce the role of private tutoring centers, Ministry of National Education announced a new model of transition from basic to secondary education in March 2007. (Ministry of National Education, 2007). OKS will be gradually abolished and students will be placed at the "special" high schools according to their examination scores at the end of the sixth, seventh and eight grades. These examinations will cover the school curricula in those years. A placement score for entry into the special high schools will be determined for each student. The three examinations will contribute 70 percent and the basic education GPA will contribute 25 percent and finally the general attitude of the student evaluated by his/her teachers will contribute five percent towards the final placement score of student. The system will be fully implemented in the 2008-2009 academic year: The process of preparation for OKS normally starts at the sixth year of basic education ad continues throughout the seventh and eight grades and student efforts intensify during the eight year. However, with the recent change in the selection system of students for special high schools most PTCs already advertised preparatory classes also for the fourth and fifth years of basic education. Şahin (2007) reported that most educators agreed that the new system will force the students to attend PTCs at earlier years than before. Recently, there is also the news of generalizing the new examination system to all of the graduates of the basic education even for determining the placement at the state general high schools to which admission currently is not restricted. (Cumhuriyet, 2007).

\subsection{B Transition to Universities}

The second national examination is called OSS (Student Selection Examination) in short and determines the advancement to Universities. It is administered by an 
independent organization called OSYM (Student Selection and Placement Center). Unlike OKS which is relevant for only for admission to "special" high schools, OSS must be taken by all students who want to be placed at a public or private university program. Not all of the 93 universities scattered around the country are considered of the same quality in terms of the job market prospects of their graduates and the salaries they command. Most of these "prestigious" universities provide instruction in English. Competition for placement at these "prestigious" universities is fierce.

Table 6 provides the selective results of a survey among high school seniors, high school graduates, university students, parents and teachers and administrators. According to Question 1 in this table 60 percent of the high school seniors stated that there is nothing in their life now more important than the university entrance examination. Further, 70 percent of the high school seniors, 68 percent of the high school graduates, 83 percent of the university graduates stated they are currently attending PTCs, while 84 percent of the parents stated that children and 92 percent of the teachers and administrators stated that their students are currently attending PTCs.

Question 5 in Table 6 asks the most important reason for attending PTCs. In response to this query, 58 percent of the high school senior students, 77 percent of the high school graduates, 57 percent of the university students and 72 percent of the teachers and administrators believed that school education is not adequate for success in university entrance examination.

Question 12 in the same table asks about the attitude of school teachers and administrators towards PTCs. The responses show that 47 percent of the high school 
seniors, 43 percent of the high school graduates and 50 percent of the university students stated that their teachers and administrators absolutely want them to attend the PTCs.

In 20061678383 applicants took the university entrance examination. Of those applicants 43 percent were fresh high school graduates and 41 percent were repeat-takers who were not placed in a university program during the earlier years, 13 percent were repeat-takers who were already enrolled at a university program and 3 percent were already graduates of a university. Thus, 57 percent were repeat-takers and 48 percent of them were placed at a program, while 43 percent were fresh high school graduates taking the examination for the first time and 44 percent of them were placed at a university program. Overall only 22 percent of the applicants could be placed at a university program (Student Selection and Placement Center, 2007).

As indicated above in the 2006 ÖSS examination 41 percent of the applicants were repeat-takers. The rather high percent of repeat-takers imply that most high school graduates spend a year or more in preparation for the examination. There is evidence that they mostly attend private tutoring centers during this period. Question 11 in Table 6 provide the hours of education per week received at the PTCs by various groups. This information indicates that 51 percent of the high school seniors attend PTCs for 10-20 hours per week while 84 percent of the high school graduates attend PTCs for 15-20 or more hours per week. This indicates that high school graduates attend PTCs for more hours per week than the other groups. This group is mostly the group of repeat-takers. This concords with the views of the providers of the PTCs that PTCs provide an alternative for the young to spending idle time at the cafes. 


\subsection{Why is there a High Demand for University Education in Turkey?}

There is a very high demand for university education in Turkey. This may be due to a number of factors. The foremost factor is the very high private monetary returns to university education in Turkey. Tansel, (1994, 2001 and 2005) show that over the years, monetary returns to a year of university education is higher than that at other levels of education by a large margin. Further, the probability of finding a job out of unemployment is higher for the university graduates than for the unemployed at other levels of education (Tansel and Taşç1, 2007). University education confers on men the advantage of serving their military service as an officer rather than as a private soldier. Finally, as it is in other countries university graduates enjoy a prestigious position in Turkish society. These advantages make university education very desirable for the young and their parents. For this reason parents are willing to invest into private tutoring of their children with great sacrifices. As remarked in the previous section, parents first spend on the PT of their children in order to place them into special high schools which are believed to increase their chances of placement at a university program. Next, parents spend on private tutoring of their children in order for their placement at a university program.

\section{Recent Developments in the Private Tutoring Centers in Turkey}

\subsection{Forms of Private Tutoring in Turkey}

As it is in other countries private tutoring is delivered in three different forms in Turkey. These different forms are reviewed in detail in Tansel and Bircan (2006). Below we give a brief account of the private tutoring forms common in Turkey. One kind is oneto-one individualized teaching by the tutor on the requested subjects at a cost agreed upon 
by the parties involved. Accomplished students of the prestigious universities as well as retired or currently active teachers are known to provide this service which is tailored to the needs of the tutee in terms of the quality and content. This is the most expensive form of private tutoring. The suppliers of this service often guarantee success of their tutees and therefore charge high prices.

The second form of private tutoring take place at the premises of the mainstream schools and thought by the mainstream teachers for pay outside of the formal class hours. These courses are organized by the school boards with the permission of the Ministry of National Education upon demand for them. Teacher participation is voluntary. This form pf private tutoring is prevalent at the elementary school level rather than at the high school level. They are organized for the students who may need extra help with their regular class-work and for the students preparing for the national entrance examination to the "special" high schools such as science high schools, Anadolu high schools and private high schools. Students participate with the suggestion of their parents who also pay for the courses the amount determined by the Ministry of National Education. Currently, this pay ranges between 1-2 USD per hour depending on the school location. Teachers are paid 80 percent of the income generated. For a class in a particular subject to be provided these must be at least ten students and the class size is limited to 20 students. In order to evaluate student performance two examinations are given each term the results of which are reviewed by the school board so as to reflect on the teacher performance with the board's suggestions for their improvement or replacement.

The third type of private tutoring in Turkey is provided by the private tutoring centers (PTC) which are school-like organizations operating for profit. Professional 
teachers teach in a class room setting. These centers are called "dersane" in Turkish. This is the most prevalent form of private tutoring with such centers being located all over the country. Although, they provide supplementary courses, to the mainstream school subjects of the elementary and secondary schools their main activity centers on examination oriented courses. Such examination oriented courses for the national examination for entry to the "special" high schools (OKS examination) and for the national examination for entry to the universities (OSS examination). Together with their express courses on the subject matter covered in the national examination they also teach techniques on how to prepare for these examinations as well as provide counseling and guidance services for the students on the choice of study fields at the universities, a choice of universities and future career selection.

PTCs also provide courses in order to prepare the participants for the language proficiency examinations for public servants (KPDS) and for the recently instituted examinations (KPSS) for the selection candidates for various stages of the public service positions. During the academic year of 2005-2006 there were a total of 1071827 PTC students: 37 percent of these students were students of basic education; 20 percent were high schools students; 43 percent were preparing for the university-ÖSS examination and 0.63 percent were preparing for KPSS examination. At each level about 52 percent of the students were boys while 48 percent were girls. However, of those preparing for the KPSS examination 42 percent were men and 58 percent were women. This indicates that more women than men are interested in seeking a public sector job.

PTC's started being organized in the early 1960's with the purpose of preparing students for the university entrance examination. They were legally recognized in 1965 
and a law passed governing their operation. They operate with a license from the Ministry of National Education and under its surveillance. They must satisfy certain criteria in order to be granted the license. They are then legally established, tax paying businesses. After their establishment, the PTCs are subject to inspection by the inspectors of the Ministry of Education just like the regular basic education schools or the high schools of the Ministry of Education.

In the early 1970's these were public discussions about the equity implication of the university entrance examination and the PTC's. Such discussions were intensified in the early 1980's during the military intervention. In 1980 government banned all PTC's. However, a year later, before the ban become effective, it was lifted mainly as a result of the lobbying activities of the Association of the Private Tutoring Centers called ÖZDEBİR. This association of PTC's is established in the 1985 with headquarters in Ankara. Currently, it has about 500 members operating a total of 800 PTC's (together with branches) all over the country. The two other smaller and less well-known associations established recently are GÜVENDER and TÖDER. GÜVENDER was established in 1991 and its members operate about 360 (together with branches) PTCs all over the country. TÖDER was established in 2003 and its members operate about 700 PTCs (together with branches) all over the country. Membership in these associations is voluntary. According to the Ministry of National Education sources in 2006 there were about four thousand PTC's with over a million students (see Table 1). ÖZDEBIR officials claimed that there are at least an additional four thousand PTCs are operating unofficially without a license from the Ministry of National Education as part of the underground economy of Turkey. They not only avoid paying taxes but also avoid 
inspection by the Ministry of National Education inspectors. These three associations administer on the same day in May a national practice ÖSS examination for their students as a practice. According to the law governing the PTCs, each PTC has to provide services free of charge to the five percent of their total students who are coming from low income families. Özdebir officials stated that in practice this often exceeds the officially required five percent for their members.

Most private centers give an initial placement examination for their applicants. These who rank very high are allowed to register for free. If later on, these students achieve a high-score in the university entrance examination ÖSS, their names and photographs are used in the advertisements of the PTCs at which they were a student.

\subsection{Recent Trends in Private Tutoring Centers}

Table 1 gives the recent developments in the number of PTC's and related statistics. During the 1975-76 academic year there were 157 PTC's throughout the country which increased to about four thousand in 2006 which is a very substantial increase in a period of 30 years (see Table 1). During the same period, the number of participating students increased from about 46 thousand to over one million. The number of teachers employed at the PTC's reached almost to 50 thousand in 2006. This indicates that today the PTC's are a significant outlet in employing people with "teacher" training. On average, over the years the PTC employed 9-12 teachers per PTC with the exception of 1980-81. Over the years the average number of students per PTC ranged around 250-290 with the exception of 1980-81. Therefore, the PTC's in Turkey can be considered of medium size. They are not very large enterprises such as those in Hong-Kong with students in the thousands 
(Bray and Kwock, 2003). Table 1 also shows the number of students per teacher in PTC's which ranged between 22-33.

Table 2 shows the recent trends and developments in the secondary schools (high schools) in Turkey. The table pertains to the all kinds of general high schools including "special" high schools as well as vocational and technical high schools. The total number of secondary schools increased from about 2 thousand in 1976 to about 8 thousand in 2007 with the total number of students reaching to about 3.4 million and teachers employed reaching to about 188 thousand. The number of students per secondary school range between 348-487. The average number of teacher per secondary school ranged between 10-29. The number of students per teacher in the range of 16-37 which is lower than in the PCT's. However, this statistic for the secondary schools is misleading. It is well-known that the number of students per teacher in vocational technical high schools is rather low (Tansel, 2002b) as compared to that in the general high schools which are more popular and therefore more crowded. On this point see the last paragraph of this section.

Until 1997, the graduates of both the general and the vocational high schools were allowed to participate in the national university entrance examination equal terms. With the changes in the university entrance system, since 1997 vocational high school graduates are allowed to enter two-year university programs in their fields of study while in the vocational high school. If they want to enter into a four-year program or follow a different study area they are allowed to sit in the university entrance examination but with a penalty in the determination of their final university entrance score. 
Although some vocational high school students and graduates attend PTC's to prepare for the national university entrance examination, the pertinent group to compare the PTC's may be the general high schools including the "special" ones. For this reason the last two rows in Table 2 provide the number of general high schools including "special" ones and the relevant statistics. The last row shows that in 2005-2006 while

there were 3986 PTCs, the number of general high schools was somewhat less with 3460. The number of PTC students was about a million while the general high schools had about twice as much students with about two million. The number of PTC teachers was about 50 thousand while the number of teachers in general high schools was about almost twice with 103 thousand. The PTCs had about half the number of students per PTC (269) that of the number of students per general high school (581). The number of teachers per PTC is about 12 while that in general high schools is about 28 . The number of students per teacher is about the same in the PTCs and general high schools. However, these all refer to the averages and it is well known that some of the general high schools especially those at the large metropolitan centers are rather crowded in terms of the number of students per teacher.

\subsection{Private Tutoring Center Students and Gender}

In developing countries, girls lag behind boys in education. Turkey is no exception. In spite of the fact that returns to women's education is higher or at least as large as those to men in Turkey, parents invest more to educating their daughters than to educating their sons (Tansel, 2002a) mainly because boys are considered to be the main providers for their parents in old-age. Education of boys are favored over that of girls especially when household resource are limited. Tansel (2002a) reports that income is a greater 
hinderence for the formal education of girls than of boys. Same may be true in case of private tutoring also.

There is very little evidence on the gender differences of students attending PTCs in the literature. Assaad and EL-Badawy (2004) address the gender issues in PT in Egypt. Kim and Lee (2002) found that there is more private tutoring expenditures for female students in Korea who may be taking expensive courses in music and arts. Tansel and Bircan (2005) found that the probability of receiving PT is lower among females in Turkey.

Table 3 shows the proportion of the male and female students at the PTCs versus among the secondary education graduates during the period of 2000-2001 to 2005-2006. The proportion of the male students is higher than that of the female students both among the PTCs and the secondary school graduates. The proportion of male students at the PTCs declined from about 55 percent in 2000-2001 to about 53 percent in 2005-2006 while the proportion of the female students increased from about 45 percent to about 48 percent during the same period. Similarly, the proportion of the male secondary education graduates declined from about 57 to 55 percent and that of the females increased from 43 to 45 percent.

In the academic year 2005-2006, the gender gap among the PTC students was about 5 percent and that among the secondary education graduates was about 9 percent. These results indicate that the gender gap among the PTC students is less than the gender gap among the secondary school graduates. In this sense there is more gender equality among the PTC students than among the graduating class of the students of secondary education. This may be a paradox since parents have to pay for PTC and while secondary education 
is mostly provided by the government free of charge. For this reason one would expect more gender equality among secondary school graduates than among the students of PTCs.

\subsection{Private Tutoring Centers and disruption of Mainstream Education}

It is in the public discussions that attending PTCs and the process of preparation for the two national examinations disrupt the formal schooling attendance. It is well known that this happens especially during the second semester for the basic school while seniors are preparing for the OKS and while the high school seniors are preparing for the ÖSS. These examinations take place in mid June. The students preparing for these examinations concentrate on attending the PTCs and on their own preparations at home rather than attending mainstream classes. For this reason most students receive false medical reports of sickness which enable them to be absent from their mainstream classes. Receiving a false medical report of sickness has become a widely accepted and an expensive process. Question 8 in Table 6 asks a question on this process: 55 percent of the high school seniors, 49 percent of the high school graduates and 44 percent of the university students said that they will receive a false medical report of sickness for their non-attendance to the school and 36 percent of the parents and 57 percent of the teachers and administrators said that their children and their students respectively will receive medical reports for non-attendance. 20-26 percent of the respondents in various categories said that they will use the legally allowed non-attendance days while about 1934 percent of the respondents stated that they will continue mainstream schools as usual.

Recently, the president of the Independent Educators Union (2007) argued that false medical reports of sickness undermine the "psychological and ethical development" of 
the children and that in this process the parents teach their children how to cheat the establishment. This is an aspect that has been overlooked hither to.

The subject matters thought in the high school senior year are not explicitly covered in the university entrance examination. For this reason students feel free not to attend mainstream classes during that year especially during the second semester. This also leads to their arrival at the universities without working knowledge of certain topics covered in the high school senior year. This has led the Ministry of Education to devise ways to increase the importance of mainstream schooling over PTCs. For instance, over the years, the high school GPA (Grade Point Average) contributes points towards university entrance along with the result of the ÖSS examination. It is also announced in 2005 and started being implemented in 2006 that the subject matters of the high school senior year will be covered in the ÖSS. However this has not prevented non-attendance. During recent, the June 2007 ÖSS examination Ministry of Education allowed one week of non-attendance for the high school senior students.

As it is mentioned in section 2.1.A the national examination for placement into special high schools (OKS examination) is recently re-organized to increase the role of high schools in the placement and thus reduce the role of PTCs. Similarly, many educators and non-governmental organizations and the authors of this paper suggest, reorganization of the ÖSS in a similar way to increase the role of high school performance in the university placement and thus reduce the role of PTCs. Suggestions are also made to administer examinations at the high school level covering the subject matter of the high school curriculum and using the result of these examinations at the university placement with a certain weight. This is expected to increase the importance 
attached to high school classes and respect for the high school teachers and prestige of the high school level education.

\subsection{Determinants of Receiving Private Tutoring}

Tansel and Bircan (2006) examined the factors that determine the household expenditures on private tutoring in Turkey. Their findings emphasize the importance of household income and parental education levels as the most important determinants of private tutoring expenditures with a larger effect of the mother's education than that of the father's education. In order to emphasize the importance of income this study further reported that among the households in the lowest income quartile about 6 percent had private tutoring expenditures however, in the highest income quartile, four times as much, about 25 percent of the households had private tutoring expenditures. Further, 54 percent of the households in the lowest income quartile spent 1-10 percent of their total monthly expenditures on private tutoring. In contrast, in the highest income quartile 71 percent of the households spent 1-10 percent of their monthly expenditures and 27 percent of the households spent 10-30 percent of their total monthly expenditures on private tutoring.

Tansel and Bircan (2005) examined the factors that contributed to the probability of receiving private tutoring. They found that the most important factor in the high school graduation ranking of the student. Those individuals with high school graduation ranking above satisfactory were more likely to receive private tutoring compared to individuals who have just passed. Graduation with high honors, honors and satisfactory rankings contributed respectively 26,17 and 9 percent to the probability of receiving private tutoring. Thus, it appears that the motivation and the ability of the individuals determine 
the probability of receiving private tutoring. This indicates that the demand for private tutoring by students of high performance students is higher which may be partly because their demands are not met at the mainstream schools.

The second most important factor determining the probability of an individual receiving private tutoring or not was the household's income. Individuals from households with higher levels of income were more likely to receive private tutoring. The third most important factor determining whether an individual received private tutoring or not is the education level of his/her parents. Here mother's education was found to contribute more to the probability of receiving private tutoring than that of the father's education. Tansel (2002-a) also found that the parental education level is the most important factor determining the educational attainment of children in Turkey after household income. In conclusion, the students with high academic ability, high household income and highly educated parents receive more private tutoring.

\section{Geographic Distribution of Private Tutoring Centers}

This section considers the geographic distribution of the PTCs in Turkey. Table 4 provides the numbers of PTCs and general high schools in each of the 81 provinces of Turkey during the academic year 2005-2006. They are listed from the provinces with the highest number of PTCs to the lowest. Istanbul has the highest number of PTCs with 630 and also the highest number of general high schools with 544. The second highest number of PTCs (with 541) and the general high schools (with 216) is Ankara. The last column in Table 4 gives the ratio of the number of private tutoring centers to that of the general high schools. The numbers larger than one in this column indicate that the number of PTCs in a province is larger than that of the general high schools while the 
numbers smaller than one indicate that the number of PTCs in a province is less than that of the general high schools. The highest concentration of PTCs is in Ankara where the number of PTCs is 2.5 times more than that of general high schools. Bursa (1.6), Antalya (1.5), Adana (1.4), Balikesir (1.4), Mersin (1.3), Mugla (1.3) and Bolu (1.3) are the other provinces with high concentration of PTCs. The provinces with low concentration of PTCs are Tunceli (0.2), Ardahan (0.3), Bilecik (0.4), Agri (0.4) Erzincan (0.4) and Aksaray (0.4) PTCs where the number of PTCs is substantially less than that of the general high schools. This may be due to low demand for PTCs in those provinces.

Table 5 shows that the percentage shares for each of the 81 provinces, of the PTC and the general high schools in total for Turkey. The provinces are listed according to their share of PTC in Turkey's total from the highest to the lowest. The third column gives the percent of the high school age population (aged 14-16) in a province in the total high school age population of Turkey. For example, Istanbul houses about 16 percent of the total PTCs in Turkey and 15 percent of the general high schools of Turkey while about 14 percent of the high-school age population of Turkey lives in Istanbul. Ankara houses about 14 percent of the PTCs and about 6 percent of the general high schools of Turkey while about 5 percent of the high school age population of Turkey lives in Ankara. Thus Ankara is singled out as the province with 15 percent of the total PTCs serving only 5 percent of the high school age population. In a way this table gives an idea about the opportunities available to the high school age population in the provinces. Therefore, this table provides information about the spatial equity in the distribution of PTCs and high schools. This table should not be interpreted as giving the full picture about the opportunities formal secondary education available in a province since this 
table gives only the information with respect to general high schools, while there are also vocational and technical high schools at the secondary education level in each of the provinces catering to the high school age population.

Table 5 shows that for most of the provinces the percent of PTCs and general high schools and high school age population are about the same such as in Izmir, Adana, Hatay, Kocaeli etc. For instance, Hatay, Kocaeli and Kayseri house about two percent of the PTCs and general high schools and two percent of the high school age population live in these provinces. Similarly, in the province such as Amasya, Nigde, Bolu, Artvin, Yalova and Kırıkkale the percent of the PTCs, the general high schools and high school age population are about the same. In some of the provinces the percent of the general high schools is larger or equals to that of the high school age population while percent of the PTCs is smaller. For instance in Tunceli, the percent of general high schools is 0.4 which higher than the percent of high school age population which is 0.1 but the percent of PTCs is only 0.1 which is equal to the percent of the high school age population. Similarly for Kastamonu, Nevsehir, Kirsehir, Karaman, Duzce, Kars, Cankiri, Sinop, Erzincan, Hakkari, Siirt, Bilecik, Gümüşhane, Kilis, Bayburt, Ardahan and some other provinces have the same or larger percent of the general high schools as the percent of the high school age population but smaller percent of PTCs.

Some of the provinces have a larger percent of high school age population but smaller share of general high schools and PTCs. Some of these provinces are Konya, Diyarbakir, K. Maras, Ş. Urfa, Ordu, Tokat, Yozgat, Erzurum, Afyon, Van, Aksaray, Mus, Bitlis, Çankırı. However, the differences are small. 
In general we observe a more equal provincial distribution of general high schools compared to the provincial distribution of PTCs. The mean number of general high schools is 46 and the mean number of PTCs is 49 . The standard deviation of the general high schools is 39 while the standard deviation of the PTCs is 42 . Thus, although the mean number of PTCs is larger than that of the general high schools, their standard deviation is also larger indicating a more unequal distribution. In general in those provinces with percent of PTCs smaller than that of the high school age population the difference is not very large. In those provinces the demand for PTCs may be small at the prices they charge and the PTCs may not be profitable to operate.

\section{Effectiveness of Private Tutoring Centers}

There is a few research examining the effect of private tutoring on academic achievement. The evidence on this point have been mixed. Some of this evidence is reviewed by Bray (2006). Limited evidence indicates that students who received tutoring have better outcomes in terms of various measures of academic achievement which included better reading performance and less grade repetition and better academic performance while some studies found no correlation between private tutoring and achievement.

The President of ÖZDEBIR stated that "There is demand for our services, because we are effective in helping students achieve their desired goals". The demand for their services could indeed be taken as the evidence of the effectiveness of PTCs. Tansel and Bircan (2005) examined a random sample of students taking part in the university entrance examination (ÖSS). They found that attending PTCs during the last year in high school increased significantly the probability of getting placed in a university program. 
Further, attending PTCs increased the test scores significantly in most of the subjects in the university entrance examination among the applicants to the university entrance examination in 2002.

Table 6 gives further information about the effectiveness of PTCs from the point of view of high school senior students, high school graduates who are PTC students, university students and other groups. In this table, the Question 3 asks the respondents to compare the quality of education at the PTCs and at the mainstream schools: The responses show that 44 percent of the high school senior students, 65 percent of the high school seniors, 65 percent of the high school graduates and 34 percent of the university students indicate that the quality of education is better at the PTCs. Interestingly, 42 percent of the teachers and administrators also indicate that the quality of education is better at the PTCs. Further, among each of these groups a substantial percent stated that PTCs teach only examination techniques. It is true that PTCs concentrate on preparing for the national examinations and multiple choice question answering techniques in the shortest possible time. For this reason development of students in the subjects that are not covered in examinations such as sports, arts, music and foreign languages are hindered during the valuable high school years. The lack of foreign language skills is especially noticeable for high school graduates. This point needs to take the attention of the Ministry of National Education. The anecdotal evidence shows the inefficiency in foreign language teaching. Even the students from "special" high schools (most of which teach in a foreign language, mostly in English) spend a year of instruction intensive in English if they are admitted to a university teaching in English. This is an indication of inefficient efforts in teaching foreign languages in Turkey. 
The Question 4, in Table 6 asks about the possibility of success at the university entrance examination without attending PTCs. A larger percentage of the respondents believed that it is difficult or not possible. In particular, among the parents teachers and administrators those who believed that the success at the university entrance examination without attending PTCs is difficult or not possible were rather very high with 68 and 63 percents respectively.

Question 10 in Table 6 asks about the satisfaction levels of the various groups with the PTCs they are attending. The responses indicate that 54 percent of the high school seniors, 67 percent of the high school graduates, 43 percent of the university students are satisfied with the PTCs their children are attending and 56 percent of the parents are satisfied with the PTCs their children are attend.

The responses to the Question 6 in Table 6 indicate that 52 percent of high school seniors, 67 percent of high school graduates and 78 percent of the teachers and administrators believe that PTCs will contribute a lot to the success at the university entrance examination.

Both of the PTCs and the general high schools provide counseling and guidance services for the students in terms of selecting study fields at the universities and future carees. Question 7 asks a comparison of the quality of counseling and guidance services at the PTC and at the maintstream schools. A high proportion of highschool graduates, university students, parents and teachers and administrators believed that these services were better at the PTC or similar in both places.

Finally, some educators claimed that PTCs are replacing the high schools also as a place where students socialize. Question 9 in Table 6, asks respondents whether they like 
the PTCs or the schools. While the percentages of the students who liked PTCs or the schools were about the same however, majority of them stated that they like both places.

\subsection{Cost of the Private Tutoring Centers}

There is no accurate information about of the cost of the PTCs. The estimates of the cost of the PTCs vary substantially according to the institutions that provide them. Question 15 in Table 6 ask about the annual payment to the PTCs. 38 percent of the high school seniors 60 percent of the high school graduates, 34 percent of the university student and 44 percent of the parents stated paying 1000-2000 YTL (800-1600 USD) per year. Most of the respondents stated paying 500-3000 YTL (400-2400 USD). However, according to the anecdotal evidence some PTCs in the mega cities of Istanbul and Ankara charge as high as 3 000-4 000 USD per year per student.

According to the estimates of TED (2005), a student who participated at the OSS Examination in 2004 spent 1646 USD per year on PTCs. Since, 1786963 students participated in the OSS-examination in 2004, TED computed the total PTC cost as 2.9 billion USD which amounts to 0.96 percent of Turkey's GNP in 2004. However, this computation is challenged by ÖZDEBİR (2007) since not all of the participants of the ÖSS-examination attended PTCs. ÖZDEBIR in place, provided the following estimate. During the academic year of 2005-2006, 800 thousand students attended the PTCs, and ten percent of the students attended free of charge as stipulated by the government. This gives the total number attending with pay as 720 thousand. Applying a differential rate of 1034 USD for those preparing for ÖSS-examination and 551 USD for those preparing OKS-examination ÖZDEBIR reaches an estimate of 618 million USD as gross income of PTCs. Which amounted to 0.16 percent of Turkey's GNP. This could be considered as 
the lower bound of the total expenditures on PTCs in Turkey. In contrast, the national government expenditures on education was 3.0 percent of the GNP of Turkey in 2006. The per capita GNP of Turkey in the same year was 5477 USD.

\section{Conclusion}

This paper reviews the recent evidence on various aspects of supplementary private tutoring in Turkey. Supplementary private tutoring has a history in Turkey going back to mid 1960s. Over the years the number of private tutoring centers increased significantly. According to the official statistics, in 2006, there were about four thousand PTCs with over one million students and about fifty thousand teachers. According to the unofficial sources, there is an additional four thousand unregistered PTCs operating as part of the underground economy of Turkey.

There is a high demand for private tutoring because students prepare for the two national selection examinations; one for placement into special high schools (OKS) and the other for placement into university programs (ÖSS). Those who receive private tutoring will be able to go to better schools and prestigious universities and finally succeed in the labor market with high paying jobs and may reach influential positions in the government. The patterns of private tutoring described for Egypt by Bray (2006) and World Bank (2002) and several other countries cited in the literature (Bray, 2006) are very much relevant in Turkey.

Students attending PTCs learn techniques of answering multiple-choice questions in a short period of time rather than develop abilities to analyze and interpret. Attending PTCs become more important for senior high school students than attending mainstream classes since university entrance examination (ÖSS) only partially covers topics thought 
in mainstream classes. For this reason, attendance to PTCs disrupts mainstream classes. Since the PTCs are examination oriented, the development of students in subjects that are not covered in the national examinations such as sports, arts, music and foreign languages are hindered during the valuable high school years. The lack of foreign language skills is especially noticeable for high school graduates. The authorities of the Ministry of National Education must pay attention to the lack of foreign language skills of students graduating from the basic education schools and the high schools both.

This paper also reviews the considerations with regards to the determinants attending PTCs, effectiveness of PTCs, costs of PTCs and geographic distribution of PTCs in Turkey with a view towards spatial equity.

The governments and educators have been much concerned about the equity implications of the PTCs. It has been argued that private tutoring contributes to social stratification and inequalities in the society. Available evidence suggests that receiving private tutoring is highly dependent on household income and parental education levels. Parents with high incomes can afford better quality and greater quantities of tutoring while poor parents can not afford the same. In the end, those who could buy private tutoring have an advantage over those who could not, in getting higher incomes and prestigious positions in the labor market eventually. However, Özdebir officials argued that those who could afford buy the services of private teachers for their children and PTCs provide services for middle income and low income families at affordable prices. In this way contribute to equal opportunity. For this reason PTCs create and contribute to social and educational inequalities. Government must consider providing scholarships to students from poor families who would like to attend private tutoring centers. 
Shortly before the ÖSS examination in mid June 2007, various youth groups organized meetings in Istanbul protesting the ÖSS examination. Further, in order to appeal to the young voters in the upcoming national parliamentary elections, the major parties all promised to abolish the ÖSS examination if they come to power. These two pieces of news give an idea about the extant of national obsession with the national university entrance examinations.

Since March 2007, OKS-examination system is redesigned by the Ministry of Education to increase the importance of mainstream education. It is the opinion of the present ÖSS-examination system must be redesigned to increase the dependence of the ÖSS-subjects to the high school curriculum. Further, new annual examinations should be introduced at the high schools just like in the basic education level in the new OKS examination system. This will be a move towards better (but not complete) provision of equitable opportunities for university education than the current system. At the same time present authors believe that Ministry of National Education must expend resources to improving the quality of education at the high schools all over the country. Providing students quality education in the high schools and participation at the national selection examination whose contents are related to the high school curriculum will be a step towards provision equal opportunities. 
Table 1: Recent Trends in Private Tutoring Centers, Students and Teachers, 1975-2007, Turkey.

\begin{tabular}{|c|c|c|c|c|c|c|}
\hline Years & $\begin{array}{c}\text { Number of } \\
\text { Private Tutoring } \\
\text { Centers }\end{array}$ & $\begin{array}{c}\text { Number of } \\
\text { Private Tutoring } \\
\text { Center Students }\end{array}$ & $\begin{array}{c}\text { Number of } \\
\text { Private Tutoring } \\
\text { Center Teachers }\end{array}$ & $\begin{array}{c}\text { Number of } \\
\text { Students per } \\
\text { Private Tutoring } \\
\text { Center }\end{array}$ & $\begin{array}{c}\text { Number of } \\
\text { Teachers per } \\
\text { Private Tutoring } \\
\text { Center }\end{array}$ & $\begin{array}{c}\text { Number of } \\
\text { Students per } \\
\text { Teacher in } \\
\text { Private Tutoring } \\
\text { Centers } \\
\end{array}$ \\
\hline $1975-1976$ & 157 & 45582 & 1.384 & 290 & 8.8 & 32.9 \\
\hline $1980-1981$ & 174 & 101703 & 3826 & 585 & 21.9 & 26.6 \\
\hline $1990-1991$ & 762 & 188407 & 8723 & 247 & 11.5 & 21.6 \\
\hline $1995-1996$ & 1292 & 334.270 & 10941 & 259 & 8.4 & 30.5 \\
\hline $2000-2001$ & 1920 & 556282 & 17300 & 290 & 9.0 & 32.15 \\
\hline $2001-2002$ & 2122 & 608716 & 19881 & 286 & 9.3 & 30.60 \\
\hline $2002-2003$ & 2568 & 668673 & 23730 & 260 & 9.2 & 28.17 \\
\hline $2003-2004$ & 2984 & 784565 & 30537 & 262 & 10.2 & 25.69 \\
\hline $2004-2005$ & 3570 & 925299 & 41031 & 259 & 11.4 & 22.55 \\
\hline $2005-2006$ & 3986 & 1071827 & 47621 & 269 & 11.9 & 22.5 \\
\hline
\end{tabular}

Source: 1975-1996: Ozdebir

2000-2006: Ministry of National Education (2006; 2007) 
Table 2: Recent Trends in Secondary Schools, Students and Teachers, 1975-2007, Turkey.

\begin{tabular}{|c|c|c|c|c|c|c|c|}
\hline \multirow{2}{*}{ Years } & \multirow{2}{*}{$\begin{array}{c}\text { Number of } \\
\text { Secondary } \\
\text { Schools }^{\mathrm{a}}\end{array}$} & \multicolumn{2}{|c|}{$\begin{array}{c}\text { Number of Secondary } \\
\text { School }\end{array}$} & \multirow{2}{*}{$\begin{array}{c}\text { Number of } \\
\text { Secondary School } \\
\text { Teachers }\end{array}$} & \multirow{2}{*}{$\begin{array}{c}\text { Number of } \\
\text { Students per } \\
\text { Secondary School }\end{array}$} & \multirow{2}{*}{$\begin{array}{c}\text { Number of } \\
\text { Teachers per } \\
\text { Secondary School }\end{array}$} & \multirow{2}{*}{$\begin{array}{c}\text { Number of Students } \\
\text { per Teacher in } \\
\text { Secondary Schools }\end{array}$} \\
\hline & & Graduates & Students & & & & \\
\hline $1975-1976$ & 2110 & 176998 & 773436 & 21079 & 367 & 10.0 & 36.7 \\
\hline $1980-1981$ & 3031 & 210370 & 1054937 & 75303 & 348 & 24.8 & 14.0 \\
\hline $1990-1991$ & 3743 & 343548 & 1426632 & 112775 & 381 & 30.1 & 12.7 \\
\hline $1995-1996$ & 4987 & 551124 & 2162865 & 145241 & 434 & 29.1 & 14.9 \\
\hline $1999-2000$ & 6000 & 536124 & 2316350 & 143379 & 386 & 24.9 & 16.2 \\
\hline $2000-2001$ & 6291 & 532952 & 2362653 & 139969 & 376 & 22.3 & 16.9 \\
\hline $2001-2002$ & 6367 & 507363 & 2579819 & 144884 & 405 & 22.8 & 17.8 \\
\hline $2002-2003$ & 6212 & 530259 & 3023602 & 137956 & 487 & 22.2 & 21.9 \\
\hline $2003-2004$ & 6408 & 683350 & 3014392 & 147776 & 470 & 23.1 & 20.4 \\
\hline $2004-2005$ & 6816 & 590834 & 3039449 & 167614 & 446 & 24.6 & 18.1 \\
\hline $2005-2006$ & 7435 & 645328 & 3258254 & 185317 & 438 & 24.9 & 17.6 \\
\hline $2006-2007$ & 7934 & - & 3386717 & 187665 & 427 & 23.7 & 18.1 \\
\hline $2005-2006^{b}$ & 3406 & 410109 & 2075617 & 102581 & 609 & 30.1 & 20.2 \\
\hline $2006-2007^{b}$ & 3690 & - & 2142218 & 103389 & 581 & 28.0 & 20.7 \\
\hline
\end{tabular}

Notes : a: The number of secondary schools, students and teacher provided in this table include all kinds of general and vocational high schools.

b: These statistics refer only to the general high schools for the period 2005-2007.

Sources: $1975-1976,1980-1981$ : SIS (1991), Table IV-3, Table IV-4.

1990-1991: SIS (1997), Table 109.

1999-2007: Ministry of National Education (2007), Table 1.6. 
Table 3: Number of Students in Private Tutoring Centers and Number of Secondary Education Graduates by gender, 2000-2006, Turkey.

\begin{tabular}{|c|c|c|c|c|c|c|}
\hline \multirow{2}{*}{ Years } & \multicolumn{2}{|c|}{ Number of Students in Private Tutoring Centers } & \multicolumn{3}{|c|}{ Number of Secondary Education Graduates } \\
\cline { 2 - 7 } & Total & Male (\%) & Female (\%) & Total & Male (\%) & Female (\%) \\
\hline $2000-01$ & 556282 & $308157(55.4)$ & $248125(44.6)$ & 532952 & $302530(56.8)$ & $230422(43.2)$ \\
\hline $2001-02$ & 608716 & $331330(54.4)$ & $277386(45.6)$ & 507363 & $280252(55.2)$ & $227111(44.8)$ \\
\hline $2002-03$ & 668673 & $361503(54.1)$ & $301170(45.9)$ & 530259 & $292670(55.2)$ & $237589(44.8)$ \\
\hline $2003-04$ & 784565 & $420979(53.7)$ & $363586(46.3)$ & 683350 & $376730(55.1)$ & $306620(44.9)$ \\
\hline $2004-05$ & 925299 & $491408(53.1)$ & $433891(46.9)$ & 590834 & $321847(54.5)$ & $268987(45.5)$ \\
\hline $2005-06$ & 1071827 & $562916(52.5)$ & $508911(47.5)$ & 645328 & $352384(54.6)$ & $292944(45.4)$ \\
\hline
\end{tabular}

Source: Ministry of National Education (2006; 2007). 
Table 4: Distribution of Private Tutoring Centers and General High Schools by Provinces, 2005-2006, Turkey*

\begin{tabular}{|c|c|c|c|c|c|c|c|c|c|c|c|}
\hline Provinces & $\begin{array}{c}\text { Number of } \\
\text { private } \\
\text { tutoring } \\
\text { centers } \\
\text { (a) } \\
\end{array}$ & $\begin{array}{c}\text { Number } \\
\text { of high } \\
\text { schools. } \\
\text { (b) } \\
\end{array}$ & $\mathbf{a} / \mathbf{b}$ & Provinces & $\begin{array}{c}\text { Number of } \\
\text { private } \\
\text { tutoring } \\
\text { centers } \\
\text { (a) } \\
\end{array}$ & $\begin{array}{c}\text { Number } \\
\text { of high } \\
\text { schools. } \\
\text { (b) } \\
\end{array}$ & $\mathbf{a} / \mathbf{b}$ & Provinces & $\begin{array}{c}\text { Number of } \\
\text { private } \\
\text { tutoring } \\
\text { centers } \\
\text { (a) } \\
\end{array}$ & $\begin{array}{c}\text { Number } \\
\text { of high } \\
\text { schools. } \\
\text { (b) } \\
\end{array}$ & $\mathbf{a} / \mathbf{b}$ \\
\hline İstanbul & 630 & 544 & 1.2 & Osmaniye & 35 & 33 & 1.1 & Aksaray & 13 & 33 & 0.4 \\
\hline Ankara & 541 & 216 & 2.5 & Ordu & 35 & 37 & 1.0 & Kastamonu & 13 & 27 & 0.5 \\
\hline İzmir & 195 & 183 & 1.1 & Adiyaman & 34 & 33 & 1.0 & Nevşehir & 13 & 27 & 0.5 \\
\hline Adana & 159 & 112 & 1.4 & Çorum & 32 & 31 & 1.0 & Kırşehir & 12 & 20 & 0.6 \\
\hline Bursa & 141 & 88 & 1.6 & Sivas & 32 & 42 & 0.8 & Şırnak & 12 & 14 & 0.9 \\
\hline Antalya & 127 & 85 & 1.5 & Çanakkale & 30 & 35 & 0.9 & Karaman & 12 & 24 & 0.5 \\
\hline Mersin & 121 & 92 & 1.3 & Erzurum & 29 & 51 & 0.6 & Bingöl & 12 & 16 & 0.8 \\
\hline Konya & 95 & 110 & 0.9 & Isparta & 29 & 43 & 0.7 & Artvin & 11 & 12 & 0.9 \\
\hline Balıkesir & 84 & 61 & 1.4 & Mardin & 28 & 25 & 1.1 & Düzce & 11 & 16 & 0.7 \\
\hline Hatay & 79 & 67 & 1.2 & Kütahya & 27 & 35 & 0.8 & Muş & 11 & 14 & 0.8 \\
\hline Kocaeli & 78 & 70 & 1.1 & Tokat & 27 & 34 & 0.8 & Bitlis & 10 & 14 & 0.7 \\
\hline Kayseri & 70 & 73 & 1.0 & Elazı̆̆ & 27 & 34 & 0.8 & Yalova & 9 & 9 & 1.0 \\
\hline Manisa & 69 & 65 & 1.1 & Yozgat & 25 & 35 & 0.7 & Kars & 9 & 19 & 0.5 \\
\hline Samsun & 67 & 58 & 1.2 & Kirklareli & 24 & 27 & 0.9 & Çankırı & 9 & 12 & 0.8 \\
\hline Diyarbakır & 59 & 54 & 1.1 & Afyon & 23 & 42 & 0.6 & Sinop & 9 & 19 & 0.5 \\
\hline Denizli & 54 & 49 & 1.1 & Edirne & 23 & 27 & 0.9 & Erzincan & 9 & 24 & 0.4 \\
\hline Trabzon & 53 & 53 & 1.0 & Kurıkkale & 22 & 21 & 1.0 & Hakkari & 9 & 14 & 0.6 \\
\hline Gaziantep & 53 & 62 & 0.9 & Giresun & 21 & 27 & 0.8 & Ăgrı & 8 & 19 & 0.4 \\
\hline Sakarya & 52 & 45 & 1.2 & Burdur & 20 & 23 & 0.9 & Bartın & 7 & 8 & 0.9 \\
\hline Muğla & 51 & 38 & 1.3 & Rize & 20 & 28 & 0.7 & Siirt & 7 & 15 & 0.5 \\
\hline Aydın & 49 & 50 & 1.0 & Uşak & 20 & 20 & 1.0 & Iğdır & 6 & 9 & 0.7 \\
\hline K.Maraş & 49 & 48 & 1.0 & Van & 20 & 39 & 0.5 & Bilecik & 6 & 15 & 0.4 \\
\hline Malatya & 45 & 65 & 0.7 & Amasya & 19 & 18 & 1.1 & Gümüşhane & 5 & 11 & 0.5 \\
\hline Eskişehir & 44 & 50 & 0.9 & Karabük & 18 & 18 & 1.0 & Kilis & 3 & 6 & 0.5 \\
\hline Ş.Urfa & 44 & 45 & 1.0 & Batman & 18 & 20 & 0.9 & Bayburt & 3 & 6 & 0.5 \\
\hline Tekirdağ & 41 & 34 & 1.2 & Niğde & 15 & 22 & 0.7 & Tunceli & 3 & 14 & 0.2 \\
\hline Zonguldak & 35 & 37 & 1.0 & Bolu & 14 & 11 & 1.3 & Ardahan & 2 & 8 & 0.3 \\
\hline
\end{tabular}

Notes:

*: The provinces are ordered by The number of private tutoring centers they have from highest to the lowest.

a: Nnumber of private tutoring centers in a province at the end of the academic year 2005-2006.

b: Number of general high schools in a province at the beginning of the academic year 2006-2007

Sources:

a and b: Ministry of National Education (2006; 2007).

c: State Institute of Statistics (2003). 
Table 5: Distribution of the Private Tutoring Centers, General High Schools and High School Age Population by Provinces, 2005-2006, Turkey

\begin{tabular}{|c|c|c|c|c|c|c|c|}
\hline Provinces & $\begin{array}{l}\% \text { Private } \\
\text { Tutoring }^{\mathrm{a}}\end{array}$ & $\begin{array}{c}\% \\
\text { High } \\
\text { School }^{\mathrm{b}}\end{array}$ & $\begin{array}{c}\% \\
\text { Pop. }^{\mathrm{c}}\end{array}$ & Provinces & $\begin{array}{l}\% \text { Private } \\
\text { Tutoring }^{\text {a }}\end{array}$ & $\begin{array}{c}\% \\
\text { High } \\
\text { School }^{b}\end{array}$ & $\begin{array}{c}\% \\
\text { Pop. }\end{array}$ \\
\hline İstanbul & 15.8 & 14.7 & 13.5 & Osmaniye & 0.9 & 0.9 & 0.8 \\
\hline Ankara & 13.6 & 5.9 & 5.3 & Ordu & 0.9 & 1.0 & 1.4 \\
\hline İzmir & 4.9 & 5.0 & 4.3 & Adiyaman & 0.9 & 0.9 & 1.2 \\
\hline Adana & 4.0 & 3.0 & 3.0 & Çorum & 0.8 & 0.8 & 0.9 \\
\hline Bursa & 3.5 & 2.4 & 2.8 & Sivas & 0.8 & 1.1 & 1.2 \\
\hline Antalya & 3.2 & 2.3 & 2.1 & Çanakkale & 0.8 & 0.9 & 0.5 \\
\hline Mersin & 3.2 & 2.5 & 2.6 & Erzurum & 0.7 & 1.4 & 1.6 \\
\hline Konya & 2.4 & 3.0 & 3.4 & Isparta & 0.7 & 1.7 & 0.7 \\
\hline Balıkesir & 2.1 & 1.7 & 1.3 & Mardin & 0.7 & 0.7 & 1.2 \\
\hline Hatay & 2.0 & 1.8 & 2.1 & Kütahya & 0.7 & 1.0 & 0.9 \\
\hline Kocaeli & 2.0 & 1.9 & 1.7 & Tokat & 0.7 & 0.9 & 1.3 \\
\hline Kayseri & 1.8 & 2.0 & 1.7 & Elazı̆̆ & 0.7 & 0.9 & 0.9 \\
\hline Manisa & 1.7 & 1.8 & 1.8 & Yozgat & 0.6 & 1.0 & 1.2 \\
\hline Samsun & 1.7 & 1.6 & 1.8 & Kirklareli & 0.6 & 0.7 & 0.4 \\
\hline Diyarbakir & 1.5 & 1.5 & 2.4 & Afyon & 0.6 & 1.1 & 1.2 \\
\hline Denizli & 1.4 & 1.3 & 1.1 & Edirne & 0.6 & 0.7 & 0.5 \\
\hline Trabzon & 1.3 & 1.4 & 1.5 & Kırıkkale & 0.6 & 0.6 & 0.6 \\
\hline Gaziantep & 1.3 & 1.7 & 2.2 & Giresun & 0.5 & 0.7 & 0.8 \\
\hline Sakarya & 1.3 & 1.2 & 1.0 & Burdur & 0.5 & 0.6 & 0.3 \\
\hline Muğla & 1.3 & 1.0 & 0.8 & Rize & 0.5 & 0.8 & 0.5 \\
\hline Aydın & 1.2 & 1.4 & 1.4 & Uşak & 0.5 & 0.5 & 0.4 \\
\hline K.Maraş & 1.2 & 1.3 & 1.7 & Van & 0.5 & 1.1 & 1.5 \\
\hline Malatya & 1.1 & 1.8 & 1.4 & Amasya & 0.5 & 0.5 & 0.5 \\
\hline Eskişehir & 1.1 & 1.4 & 0.9 & Karabük & 0.5 & 0.5 & 0.3 \\
\hline Ş.Urfa & 1.1 & 1.2 & 2.7 & Batman & 0.5 & 0.5 & 0.8 \\
\hline Tekirdağ & 1.0 & 0.9 & 0.8 & Niğde & 0.4 & 0.6 & 0.5 \\
\hline Zonguldak & 0.9 & 1.0 & 1.0 & Bolu & 0.4 & 0.3 & 0.3 \\
\hline
\end{tabular}

\begin{tabular}{|c|c|c|c|}
\hline Provinces & $\begin{array}{c}\% \\
\text { Private } \\
\text { Tutoring }\end{array}$ & $\begin{array}{c}\% \\
\text { High } \\
\text { School }^{\mathrm{b}}\end{array}$ & $\begin{array}{c}\% \\
\text { Pop. }\end{array}$ \\
\hline Aksaray & 0.3 & 0.9 & 0.7 \\
\hline Kastamonu & 0.3 & 0.7 & 0.5 \\
\hline Nevşehir & 0.3 & 0.7 & 0.5 \\
\hline Kırşehir & 0.3 & 0.5 & 0.4 \\
\hline Şırnak & 0.3 & 0.4 & 0.5 \\
\hline Karaman & 0.3 & 0.7 & 0.4 \\
\hline Bingöl & 0.3 & 0.4 & 0.5 \\
\hline Artvin & 0.3 & 0.3 & 0.3 \\
\hline Düzce & 0.3 & 0.4 & 0.4 \\
\hline Muş & 0.3 & 0.4 & 0.9 \\
\hline Bitlis & 0.3 & 0.4 & 0.7 \\
\hline Yalova & 0.2 & 0.2 & 0.2 \\
\hline Kars & 0.2 & 0.5 & 0.5 \\
\hline Çankırı & 0.2 & 0.3 & 0.4 \\
\hline Sinop & 0.2 & 0.5 & 0.4 \\
\hline Erzincan & 0.2 & 0.7 & 0.5 \\
\hline Hakkari & 0.2 & 0.4 & 0.4 \\
\hline Ağrn & 0.2 & 0.5 & 1.0 \\
\hline Bartın & 0.2 & 0.2 & 0.3 \\
\hline Siirt & 0.2 & 0.4 & 0.4 \\
\hline Iğdır & 0.2 & 0.2 & 0.3 \\
\hline Bilecik & 0.2 & 0.4 & 0.2 \\
\hline Gümüşhane & 0.1 & 0.3 & 0.3 \\
\hline Kilis & 0.1 & 0.2 & 0.2 \\
\hline Bayburt & 0.1 & 0.2 & 0.2 \\
\hline Tunceli & 0.1 & 0.4 & 0.1 \\
\hline Ardahan & 0.05 & 0.2 & 0.2 \\
\hline
\end{tabular}

\begin{tabular}{|l|c|c|c|}
\hline Turkey & 100 & 100 & 100 \\
\hline
\end{tabular}

Notes:

*: The provinces are ordered by The number of private tutoring centers they have from highest to the lowest.

a: Percent of the number of private tutoring centers in a province in the total number of private tutoring centers in Turkey at the end of the academic year $2005-2006$.

b: Percent of the number of general high schools in a province in the total number of general high schools in Turkey at the beginning of the academic year 2006-2007

c: Percent of the high school age population (14-16) in a province in the total high school age population of Turkey in 2000 general census of population.

Sources:

a and b: Ministry of National Education (2006; 2007).

c: State Institute of Statistics (2003). 
Table 6: Selected Results of a Survey on Private Tutoring Centers (PTC) Conducted by TED, Turkey, 2005.

\begin{tabular}{|c|c|c|c|c|c|}
\hline & $\begin{array}{l}\text { High School Senior } \\
\text { Students } \%\end{array}$ & $\begin{array}{l}\text { High School } \\
\text { Graduates }^{\mathrm{a}} \%\end{array}$ & $\begin{array}{l}\text { University } \\
\text { Students }{ }^{\mathrm{b}} \%\end{array}$ & Parents $^{c}$ & $\begin{array}{c}\text { Teachers and } \\
\text { Administrators }{ }^{\mathrm{d}} \%\end{array}$ \\
\hline Number Interviewed & 1078 & 1073 & 1064 & 1103 & 486 \\
\hline \multicolumn{6}{|c|}{ 1. Is There Anything in Your Life Now More Important Than The University Entrance Examination? } \\
\hline a. Yes & 24 & 21 & - & - & - \\
\hline b. No & 60 & 66 & - & - & - \\
\hline \multicolumn{6}{|c|}{ 2. Are You Currently Attending PTCs? } \\
\hline a. Yes & 70 & 68 & 83 & 84 & 92 \\
\hline b. No & 25 & 23 & 16 & 14 & 6 \\
\hline \multicolumn{6}{|c|}{ 3. Where is the Quality of Education Better in? } \\
\hline a. PTC & 44 & 65 & 34 & - & 42 \\
\hline b. Schools & 6 & 3 & 10 & - & 5 \\
\hline $\begin{array}{l}\text { c. PTC Teach Only } \\
\text { Examination Techniques }\end{array}$ & 17 & 20 & 32 & - & 31 \\
\hline
\end{tabular}

4. Possibility of Success at University Entrance without PTC?

\begin{tabular}{|l|l|l|l|l|l|}
\hline a. Possible & 44 & 35 & 49 & 21 \\
\hline b. Difficult or Not Possible & 58 & 64 & 50 & 68 & 63 \\
\hline
\end{tabular}

5. The Most Important Reason for Attending PTCs

a. School Education is not Adequate for Success in University Entrance Examination

\begin{tabular}{l|l|l|l|}
58 & 77 & 57 & - \\
& & &
\end{tabular}

6. How Much Do You Believe that PTC will Contribute to Your Success at the University Entrance Examination?

\begin{tabular}{|l|c|c|c|c|c}
\hline a. Will Contribute a Lot & 52 & 67 & - & - \\
\hline b. Will not Contribute Much & 16 & 14 & - & - \\
\hline c. Will not Contribute & 3 & 3 & - & - \\
\hline
\end{tabular}

7. Where is the Quality of Counseling and Guidance Services Better at?

\begin{tabular}{|l|c|c|c|c|c|}
\hline a. PTC & 38 & 52 & 35 & 32 & 45 \\
\hline b. Schools & 8 & 4 & 12 & 12 \\
\hline c. Both Places & 36 & 30 & 27 & 49 \\
\hline
\end{tabular}

8. How Does Preparing for the University Examination Affect your Second Semester School Attendance?

\begin{tabular}{|l|c|c|c|c|c|}
\hline a. Will receive Medical Report & 55 & 49 & 44 & 36 & 26 \\
\hline $\begin{array}{l}\text { b. Will Use Allowed } \\
\text { Non-Attendance Days }\end{array}$ & 24 & 21 & 25 & 8 \\
\hline c. Will Continue School & 19 & 29 & 29 & 34 & 32 \\
\hline
\end{tabular}

9. Do You Like Schools or PTC?

\begin{tabular}{|l|l|l|l|l|l|}
\hline a. PTC & 23 & 29 & - & - \\
\hline b. Schools & 20 & 22 & - & - \\
\hline c. Both Places & 30 & 37 & - & - \\
\hline
\end{tabular}

10. Are You Satisfied with the PTC You are Attending? 


\begin{tabular}{|l|c|c|c|c|c|}
\hline a. Yes & 54 & 67 & 43 & 56 & - \\
\hline b. Partly & 18 & 28 & 36 & 27 & - \\
\hline c. I regret & 5 & 4 & 11 & 2 & - \\
\hline \multicolumn{5}{|c|}{ 11. How Many Hours of Education per Week Do You Get at PTCs? } \\
\hline a. 0 - 10 Hours & 13 & 6 & 16 & & \\
\hline b. 10 - 15 Hours & 36 & 6.9 & 29 & & \\
\hline c. $15-20$ Hours & 15 & 51 & 28 & & \\
\hline d. $20+$ Hours & 8 & 33 & 15 & & \\
\hline
\end{tabular}

12. What is The Attitude of your School Teacher and Administrators Towards PTCs?

\begin{tabular}{|l|l|l|l|l|l|}
\hline a. Do not Think Necessary & 12 & 17 & 10 & - \\
\hline b. Absolutely Want Me to Go & 47 & 43 & 50 & - \\
\hline c. No Comment & 40 & 40 & 39 & - \\
\hline
\end{tabular}

13. Is the Quality of High School Important Determinant of Success at University Entrance Examination?

\begin{tabular}{|l|c|c|c|c|c|}
\hline a. Yes & 67 & 67 & 67 & - \\
\hline b. Partly & 26 & 26 & 26 & - & -1 \\
\hline c. No & 7 & 6 & 7 & - & 1 \\
\hline
\end{tabular}

14. While Choosing a High School for your Child Did you Consider

Past Performance of the High School at the University Entrance Exam?

\begin{tabular}{|l|l|l|l|l|l|}
\hline a. Yes & - & - & - & 50 & - \\
\hline b. No & - & - & - & 49 & - \\
\hline
\end{tabular}

15. How Much will you Pay to the PTCs this year?

\begin{tabular}{|c|c|c|c|c|c|}
\hline Less than 500 YTL & 5 & 2 & 9 & 4 & - \\
\hline $500-1000 \mathrm{YTL}$ & 12 & 17 & 28 & 17 & - \\
\hline $1000-2000 \mathrm{YTL}$ & 38 & 60 & 34 & 44 & - \\
\hline 2000-3000 YTL & 10 & 14 & 8 & 14 & - \\
\hline $3000-4000 \mathrm{YTL}$ & 3 & 1 & 4 & 7 & - \\
\hline Over $4000 \mathrm{YTL}$ & 5 & 2 & 3 & 1 & - \\
\hline No Reply & 28 & 4 & 15 & 13 & \\
\hline
\end{tabular}

Notes: a: High school graduate and attending Private Tutoring Centers.

b: University Preparatory School or first year university students. The questions addressed to this group refer to their experiences prior to their success at the university entrance examination.

c: The questions addressed to this group refer to their experiences with regards to their children.

d: Teachers and administrators of secondary Schools and Private Tutoring Centers. The questions addressed to this group refer to their experiences with regards their students.

Source: Turkish Educational Association (TED) (2005). Various Tables. 


\section{References}

Akgün, M. (2005). Ozel Dersanelere Ayrılan Ekonomik Kaynakların incelenmesi (An investigation of the Economic Resources Devoted to Private Tutoring Centers). Paper presented at the Educational Sciences Congress, 28-30 September, 2005, Pamukkale University, Denizli, Turkey.

Assaad, R. and A. El-Badawy (2004) Private and Group Tutoring in Egypt: Where is the Gender Inequality? Paper presented at the workshop on Gender Work and Family in the Middle East and North Africa, University of Minnesota.

Bray, M. 1999. The shadow education system: private tutoring and its implications for planners. Fundamentals of educational planning No. 61. Paris: UNESCO International Institute for Educational Planning.

Bray, M. 2003. Adverse effects of private supplementary tutoring: dimensions, implications, and government responses. Paris: UNESCO International Institute for Educational Planning.

Bray, M. 2006. Private Supplementary Tutoring: Comparative Perspectives on Patterns and Implications, Compare, 36 (4), 515 - 530.

Bray, M. \& Kwok, P. 2003. Demand for private supplementary tutoring: conceptual considerations, and socio-economic patterns in Hong Kong, Economics of Education Review, 22 (6), 611-620.

Cumhriyet Newspaper. 2007. Genel Liselerde Sınav Dönemi (Examinations Period in the General High Schools) April 2, 2007. 
Gök, Fatma. 2006. Üniversiteye Girişte Umut Pazarı: Özel Dershaneler (Expectations Market in the Entrance to Universities: Private Tutoring Centers), Eğitim, Bilim, Society, 8: 102-109.

GÜVENDER (Güven Dershane Sahipleri Derneği) (Association of the Owners of Güven Private Tutoring Centers), 2007. http://www.guvender.org.tr/ (Accessed in May 2007).

Güvercin, G. (2005) Özel Dersanelerde ve MEB'e Bağlı Okullarda Öğretmenlik Yapan Öğretmenlerin, Öğretmenlik Mesleği ile İlgili Tutumlarının Karşılaştırılması, Özel Dersanelerde Öğrenim Gören Lise-3 Öğrencilerinin Dersaneye İlişkin Görüşleri (A Comparision of the Views of Private Tutoring Center teachers and Ministry of National Education Teachers on Teaching Profession, Views of High School. Senior Students Who Are Attending Private Tutoring Centers on Private Tutoring Centers) Paper Presented at the Educational Sciences Congress, 28-30 September, 2005, Pamukkale University, Denizli, Turkey.

Higher Education Board of Turkey (Yüksek Öğretim Kurumu) (YÖK). 2007. http://www.yok.gov.tr/ (Accessed in May 2007).

Higher Education Board of Turkey (Yüksek Öğretim Kurumu) (YÖK). 2007. Türkiye'nin Yüksek Öğretim Stratejisi (Higher Education Strategy for Turkey), Ankara, Yüksek Öğretim Kurumu.

Independent Educators Union (Bağımsız Eğitimciler sendikası) (2007) Çocuklarımızı Sahtekarlığa Alıştırıyoruz. (We Allow Our Children to Cheat). Press Release, May 24, 2007 Ankara. 
Ministry of National Education. 2006., Education Statistics of Turkey, 2005-2006, Ankara: Ministry of National Education Strategy Development Presidency.

Ministry of National Education. 2007. National Education Statistics, Formal Education, 2006-2007, Ankara: The Ministry of Education, the Presidency of Strategy Development.

Ministry of National Education. 2007. Ortaöğretime Geçiş Modeli (A Model of Transition to the Secondary Education), http://www.meb.gov.tr/

ÖZDEBİR (Özel Dershaneler Birliği) (Association of Private Tutoring Centers). 2007. http://www.ozdebir.org.tr/ (Accessed in May 2007).

Silova, I. and M. Bray (eds.) Education in the Hidden Market Place: Monitoring of Private Tutoring. Newyork: Open Society Institude.

State Institute of Statistics (SIS) 1991. Statistical Indicators 1923-1990, Ankara: State Institute of Statistics. Publication No: 1472.

State Institute of Statistics (SIS) 1997., Statistical Yearbook of Turkey, 1996, Ankara: State Institute of Statistics. Publication No: 1985.

State Institute of Statistics (SIS) 2003., 2000 Census of Population: Social and Economic Characteristics of Population, Books for the provinces. Ankara: State Institute of Statistics. 
Stevenson, D. L. \& D. P. Baker, 1992. Shadow education and allocation in formal schooling: transition to university in Japan, American Journal of Sociology, 97 (6), 1639-1657.

Student Selection and Placement Center (Öğrenci Seçme ve Yerleştirme Merkezi) (ÖSYM), http://www.osym.gov.tr (Accessed in May 2007).

Şahin, Zeynep. 2007. Eğitimciler Yeni Siystemin Öğrencileri Dersaneye zorlayacağını Vurguladilar, (Educators Emphasized That the New System Will Force the Students to Private Tutoring), Cumhuriyet Newspaper, 20 March, 2007.

Tansel, A. 1994. Wage employment, earnings and returns to schooling for men and women in Turkey. Economics of Education Review, 13 (4), 305-320.

Tansel, A. 2001. Self-employment, wage employment and returns to schooling by gender in Turkey. In Labor and Human Capital in the Middle East: Studies of markets and household behavior (pp. 337-367) ed. By Djavad Salehi-Isfahani. Reading: Ithaca Press.

Tansel, A. 2002a. Determinants of schooling attainment for boys and girls in Turkey: Individual, household and community factors. Economics of Education Review, 21, 455-470.

Tansel, A. 2002b. "General versus Vocational High Schools and Labor Market Outcomes in Turkey", in Human Capital: Population Economics in the Middle East, ed. by İsmail Sirageldin, Cairo: Economic Research Forum and American University of Cairo Press. 
Tansel, A. 2005. Public-private employment choice, wage differentials and gender in Turkey. Economic Development and Cultural Change, 53 (1), 453-477.

Tansel and Bircan. 2005. Effect of Private Tutoring on University Entrance Examination Performance in Turkey, Economic Research Forum WP No. 0407, Cairo, Egypt and IZA Discussion Paper No. 1609, Bonn, Germany.

Tansel, A. \& Bircan, F. 2006. Demand for education in Turkey: a Tobit analysis of private tutoring expenditures, Economics of Education Review, 25 (4), 303-313.

Tansel, A. and H. Mehmet Taşç1. 2007. Explaining Unemployment Duration for Men and Women in a Developing Country: The Case of Turkey. Mimeo. Ankara: Department of Economics, Middle East Technical University.

TÖDER (Tüm Özel Öğretim Kurumları Derneği)(Association of All Private Educational Establishments). 2007. http://www.toder.org/ (Accessed in May 2007)

Trade Union of Educators (Eğitim-Sen) (Eğitimciler Sendikası) 2007. http://www.egitimsen.org.tr/ (Accessed in May 2007)

Turkish Educational Association (Türk Eğitim Derneği) (TED). 2005. Türkiye'de Üniversite'ye Giriş Sistemi Araştırması ve Çözüm Önerileri (Study on the University Placement System in Turkey and Suggestions for Solution), Ankara: Türk Eğitim Derneği.

World Bank. 2002. Arab Republic of Egypt: education sector review—progress and priorities for the future, Washington DC: The World Bank. 